\title{
Innovations in the Federal Government During the Post-new Public Management Era
}

\author{
Inovações no Governo Federal Durante a Era pós Nova Gestão Pública
}

Pedro Cavalcante ${ }^{1}$

iD https://orcid.org/0000-0001-7635-695X

Instituto de Pesquisa Econômica Aplicada, Diretoria de Estudos e Políticas do Estado, das Instituições e da Democracia, Brasília, DF, Brasil ${ }^{1}$

Artigo recebido em 31.01.2018. Última versão recebida em 04.09.2018. Aprovado em 15.10.2018. 


\title{
Resumo
}

O principal objetivo do artigo é analisar se as inovações no governo federal seguem as tendências internacionais da administração pública, especialmente, na Era pós Nova Gestão Pública (NGP). O artigo, como uma pesquisa exploratória descritiva, investiga quais são as tendências, em termos de princípios e diretrizes de gestão mais presentes, evolução no tempo e relacionamento entre elas e as áreas temáticas de inovação. Para tanto, o artigo parte de uma revisão de literatura que mapeia essas tendências. Em seguida, análise de conteúdo é aplicada para verificar essas relações com base as iniciativas finalistas do Prêmio Federal de Inovação de Gestão Pública (PFIGP) de 2007 a 2015. Os resultados empíricos confirmam que 90\% delas possuem ao menos um princípio/diretriz do pós-NGP, sendo as mais recorrentes colaboração/parceria; coordenação/controle e participação/engajamento, com poucas diferenças entre finalistas e vencedores do prêmio. Ao comparar as tendências de acordo com os tipos de inovação (áreas temáticas), nota-se que a heterogeneidade entre elas é a regra. O tipo mais frequente, novo arranjo institucional, está relacionado à colaboração e parceria, enquanto as iniciativas da área meio, como orçamento e avaliação e monitoramento, apresentam princípios/diretrizes menos comuns, como fortalecimento da burocracia e liderança.

Palavras-chave: nova gestão pública; reformas administrativas; tendências de gestão; inovação.

\begin{abstract}
The main goal of this paper is to analyze whether innovations in the federal government follow public management trends, especially in the post-New Public Management (NPM) era. The article, based on exploratory descriptive research, investigates the most frequent trends in terms of principles and guidelines, their evolution in time and the relationship among the trends, and the thematic area of the innovations. To accomplish the goal, we initially conducted a comprehensive literature review to map the post-NPM trends. Next, we used content analysis to verify these initiatives based on the Federal Award of Public Management Innovation (FAPMI) from 2007 to 2015 . The empirical findings confirm that more than $90 \%$ of these initiatives have at least one post-NPM principle/directive. The recurrent initiatives are collaboration/partnership, coordination/control, and participation/engagement with minor differences between the FAPMI runners-up and winners. A comparison of the trends according to innovation type, depicted by their thematic areas, revealed an overall heterogeneity among these trends. The most frequent type - new arrangement - is highly related to collaboration and partnership, while internal ends initiatives have less common post-NPM principles/directives, such as strengthening bureaucracy and leadership.
\end{abstract}

Keywords: new public management; administrative reforms; management trends; innovation.

JEL Codes: H83, O35, G18. 


\section{Introduction}

In the last decades, economic, social, and political-administrative transformations have generated a variety of restructuring processes and, consequently, important results in the Brazilian public sector. The country has experienced several advances regarding socioeconomic indicators and the quality of public services. Notwithstanding the improvements in the economic sphere, especially the monetary stability initiated with the Real Plan (1994) and recent middle-class growth (after 2004), an exclusively economic explanation seems to be insufficient to interpret Brazilian development over the last twenty years, particularly because average growth of the GDP was low in comparison with international patterns.

An alternative explanation may come from the efforts of the Brazilian government in building innovative capacity to formulate and implement effective public policies, despite the recurrent structural limitations such as fluctuations in revenues. Hence, it has helped improve the access and quality of public services and, subsequently, caused a positive impact on socioeconomic indexes.

In this context, the main goal of this paper is to analyze whether the innovations of the Brazilian federal government have followed the trends of international public management, especially in the postNPM era. Furthermore, as an exploratory descriptive research, it investigates the more frequent trends in terms of principles and guidelines, their evolution in time and the relationship between them, and the thematic areas of the innovations.

Based on the internationally widespread propositions of New Public Management (NPM), in 1995, the federal government initiated a reformist project focused on rearranging the scope of state intervention and the overhaul of the allegedly inefficient bureaucratic model. The project, called PDRAE (Directive Plan for the Reform of the State Apparatus) proposed, among other issues, the reduction of state activities by privatizing and publicizing some governmental sectors and the operation of the government strategic core with a regulatory role. Therefore, instead of the inflexibility and inefficiency that were supposedly the hallmarks of the administrative framework, the public service would become a results-oriented management organization, similar to the private sector. After partial approval for the 1995 reform, the new government that took over in 2003 did not present a distinctive proposal of the administrative reform; however, many changes implemented previously were kept and new ones were introduced.

Consequently, the key concern of this article does not include proving the causal relationship between innovations in the public sector and development, which is an assumption of this research on management capacity in Brazil. More specifically, the paper aims to investigate the innovative capacity of the Brazilian government by focusing on the convergence/divergence of Brazilian innovation with the trends of international public administration in terms of management principles and directives. This study is relevant because the public sector is increasingly adopting innovations as a strategy (Organisation for Economic Co-operation and Development [OECD], 2018); however, empirical knowledge on this subject is still in the early stage, primarily in Brazil.

As a methodological strategy, the inquiry departs from a literature review that maps the post-New Public Management (NPM) trends, from 2007 to 2017, described in detail in the following sections. Thus, content analysis was systematically used to analyze the initiatives of the final round of the Federal Award of Public Management Innovation (FAPMI). We used qualitative software (Atlas TI) to investigate the extent to which innovations in the Brazilian government have followed cutting-edge management principles and directives and their features. Then, we categorized the initiative reports using the keywords related to the meaning of the trends. Finally, we used descriptive and networking analyses to discuss the results. 


\section{Reforms and Administrative Policies in Brazil}

The Brazilian public administration is well known for its comprehensiveness and complexity. Moreover, another feature that deserves academic attention is its high level of heterogeneity, primarily due to the socioeconomic disparities between the federal and subnational level. As a result, historically, the central government's capacity to formulate and implement policies and management initiatives is far more structured than that of the states and local government.

While some interesting innovations have been generated at subnational level, such as participatory budgeting, most of the reforms and improvements are based on decisions made at federal level. In the past century, Brazil, like many other countries, has gone through administrative reforms in response to constant transformations in the public sector and in society. However, like other Latin American countries, Brazil has always lagged behind regarding management trends. The focus of this section is to present an overview of the evolution of the Brazilian public administration, especially after the New Public Management movement.

Obviously, the public administration framework is not a result of a single historic moment or the decision of one particular government. Instead, the inherent complexity involves a broad set of transformations susceptible to socioeconomic changes that do not necessarily converge from an ideological point of view. Any conjectural analysis to explain nation public management should refer to its evolution and developmental process with all its variables and historic phases.

A dictatorial regime introduced the first real administrative reform in the 1930s due to an increasing process of modernization and intense economic and social transformation. Brazil passed from an agrarian to an industrial economy; however, the public administration, at that moment, was far from the traditional model of public bureaucracy in Weberian terms. Instead of bureaucratic rules and procedures, the structures and processes of the state apparatus were mainly oriented toward patrimonialism, which fostered the behavior and culture of patronage, corporatism, and corruption.

The administrative reform aimed to align a more interventionist role of the State with professional public bureaucracy, grounded in the Weberian bureaucratic assumptions (Torres, 2012). In this sense, the government created new agencies that selected civil servants based on exam results and technical qualification. The main guideline was to promote rationalization of methods in the public service and budgeting process (Costa, 2008). Despite the government's priorities, the results were far from expected. On the one hand, the authoritarian modernization introduced important components of Weberian bureaucracy; on the other, only a few agencies actually adopted these features. In this hybrid setting of public management, some islands of bureaucratic excellence were surrounded by an ocean of patrimonialism (Matias-Pereira, 2008).

Years later, Brazil experienced its second major administrative reform during another dictatorial regime, only this time ruled by the military. The reform, materialized by decree-law $\mathrm{N}^{\mathrm{o}} 200$ of $1967^{(1)}$, is considered as the most systematic and ambitious project to change the federal government framework and mode of operation (Costa, 2008). Overall, the decree-law aimed to reorganize the federal public administration, the rules, and procedures regarding budgetary and financial management, the civil service structure, and government procurement. The reform was grounded in five main principles: (a) coordination; (b) control; (c) planning; (d) devolution; and (e) decentralization. This last principle was widely implemented since almost three hundred public companies and seventy indirect administration agencies were created during the years following the publication of the decree (Torres, 2012).

At the end of the military regime, another initiative was undertaken to reform public management. The Ministry of Debureaucratization, created in 1979, launched a national program with the same name (Programa Nacional de Desburocratização) to simplify and rationalize organizational norms and make the public sector more dynamic and agile. The initiative aimed at dealing with the loss of control over several indirect administrative agencies. Multiplied after decree-law $\mathrm{N}^{\circ} 200$, it improved service provision to society and facilitated budgeting and personnel management (Costa, 2008; Torres, 2012). 
The program did not achieve the expected outcomes, which contributed to the ministry's extinction. It is also worth mentioning that most of the actions and the main principles of the program were not in line with the administrative reforms based on the NPM assumptions that were starting to dominate the agenda of developed countries in this period.

In the second half of the 1980s, Brazil began an intense democratization process that ended with the Federal Constitution of 1988. Some crucial guidelines for policymaking were established, such as social participation, decentralization, as well as universal principles in the social security system. In terms of management, the Constitution may be considered a reversal in some aspects regarding procurement and civil service stability, recruitment, and retirement rules (Pereira, 1999; 2002). In contrast, stronger planning and budgeting tools, social and external/internal control, and the establishment of some directives regarding mandatory public examination for all permanent careers and government schools helped drive the public sector towards a professionalized bureaucracy.

The first elected president after the military regime, Fernando Collor, embraced the Washington Consensus Agenda that focuses on layoff and privatization policies. Before his impeachment two and a half years later, the Nation Program of Privatization sold over seventy public companies, especially in former state monopolies, such as energy, telecommunications, mining, and oil. The process and results were highly criticized because of the intense downsizing and privatization without proper debate among important social groups (Costa, 2008; Torres, 2012).

The New Public Management guidelines were incorporated into the federal government in the first Cardoso administration (from 1995 to1998). A special department was created to lead the reform (Ministerio da Administracao Federal e da Reforma do Estado [MARE]). Cardoso appointed a former minister of economy to run the program, Pereira (2002), who relied on Anglo-Saxon experiences to make public administration rules more flexible through a management reform and overcome the performance deficit of the Brazilian public sector.

The program, called Plano Diretor de Reforma do Aparelho do Estado (Brazil, 1995) aimed at:

Increasing the state's governance, understood as its administrative capacity to govern effectively and efficiently, focusing on public services for citizens;

Restricting the state's roles in essential functions;

Decentralizing almost all social policies to states and municipalities;

Partially transferring regional policies from the Union to the states and promote cooperation among them.

In conclusion, the ambitious goals had different results. On the one hand, the privatization initiatives were successful along with the creation of agencies to regulate the privatized sectors, fostering the culture of policy evaluation (especially of performance), and with the decentralization of social policies and some innovations linked to planning and budgeting (Abrucio, 2007; Costa, 2008; Gaetani, 2003). On the other, the effort to incorporate instruments of personnel management in the public service and the project of publicization, i.e. transferring responsibility to society to manage social policy, similar to the quasi-autonomous non-governmental organization (quangos) in the UK, were in no way implemented. Regardless, the publicization front has been widespread at subnational level in many areas such as education and health (Abrucio, 2007; Brulon, Ohayon, \& Rosenberg, 2012; Pereira, 2002).

In 2003, Brazil experienced a change of government with a left-wing party (Workers' Party - PT) leading the executive branch for the first time. Although the discourse was intensely against administrative reforms - a consequence of neoliberal movements - some initiatives from the previous governments were still on the agenda. The Workers' Party administration decentralized the social policy to local governments, privatized public services, reformed the pension system, and introduced policies towards management performance (Abrucio, 2007; Abrucio \& Gaetani, 2008). However, the civil service began a reorganization process based on increasing personnel and diversifying careers under the 
discourse of state development (Cavalcante \& Carvalho, 2017). Moreover, the administrative policies highlighted participation, transparency, and policy evaluation as crucial values for public management.

Although any mention of administrative reforms was frowned upon during the Workers' Party (PT) government, our empirical analysis shows that the public policies and innovations implemented at the time were detached from international management trends.

\section{The Post-New Public Management Trends}

The historical approach is important to contextualize the extent to which the management movement and, subsequently, the administrative reforms have affected the public sector framework in Brazil. The major reform strategies have fallen into disuse, primarily because of the high transactional costs that the most radical changes tend to generate. The obstacles and resistance inherent in the reform process produce results that are usually far from the expected outcomes.

Therefore, more recently, governments worldwide have preferred to focus on specific and continual improvements in processes and services, which Pollitt and Bouckaert (2004) call microimprovements. They may also be understood as innovations in management that are increasingly gaining a strategic dimension in the public sector. Despite the variety of concepts, innovations in government are usually related to the upgrading of organizational processes and the implementation of new products, procedures, services, policies or systems (Bekkers, Edelenbos, \& Steijn, 2011; De Vries, Bekkers, \& Tummers, 2016; Osborne \& Brown; 2005).

Before analyzing the convergence/divergence of the innovations in the Brazilian federal government with public management trends in terms of principles and directives, the present paper presents these trends and the method used to summarize them. It also presents our literature review regarding the evolution of public administration after the hegemony of the New Public Management (NPM) (Pollitt \& Bouckaert, 2004).

For the review, we analyzed books of reputable publishers in the field of public administration and major international academic journals ${ }^{(2)}$ from 2007 to 2017. The descriptors were new public management; public service reform; post new public management; administrative reform; and public management reform. We selected twenty-five (25) books and fifty-nine (59) articles, including comparative analyses and country-specific case studies. Both types of publications are predominantly based on research in developed countries. In short, this diversity in the literature reinforces the importance of the subject in contemporary academic circles.

The outputs and consequences of the administrative reforms converge at some points. The first point involves the vision of gradualism and continuity after NPM rather than a large overhaul. Christensen and Lægreid (2007) argue that New Public Management has a restrictive effect on the subsequent reforms. In general, the process is neither convergent nor divergent and each trajectory is restricted by the specific internal and external contexts, administrative traditions, and the history of each government. Reformist experiences are even more difficult to analyze from a single perspective since variations are the rule rather than the exception.

The new post-NPM trends do not mean that the characteristics of NPM are disappearing. For instance, performance management and focus on results/impacts continue in the agenda. In practice, the third generation of on-going reforms reflects the successes and failures of the reforms of the previous decades (Greve, Lægreid, \& Rykkja, 2016)

State reforms include distinct models or NPM variations that converge on the advancement of the premise of NPM but emphasize different assumptions and management mechanisms that, in some cases, are repeated in the models or paradigms. In other words, they overlap depending on the political forces, path dependence, and historical backgrounds of the nations involved (Pollitt \& Bouckaert, 2004). 
It is important to note that the complexity of developing such models/paradigms tends to generate difficulties and skepticism in the analytical capacities of simplification; as Goldfinch and Wallis (2010, p. 1108) argue. "where NPM has not been adopted substantively ... it is problematic to propose a shift to a post-NPM world, when there has never been one of NPM."

Undoubtedly, this is not a trivial exercise, but significant changes have occurred in the way the public sector has operated in the last decades - which differ from the management tendencies propagated between the late 1970s and early 1990s. Therefore, it is now time to move forward in the attempt to identify the characteristics of the so-called post-NPM period. Table 1 summarizes these trends in terms of principles and guidelines of public management. The ordering follows the frequency of recurrence in the articles and books analyzed in the literature review.

Table 1

\section{Post-NPM Trends}

\begin{tabular}{|c|c|c|c|}
\hline Principles and Guidelines & Meaning & Keywords & Authors \\
\hline $\begin{array}{l}\text { Collaboration and } \\
\text { Partnership }\end{array}$ & $\begin{array}{l}\text { Collaborative } \\
\text { processes and } \\
\text { partnerships in a } \\
\text { variety of ways - } \\
\text { within the public } \\
\text { sector, with the } \\
\text { private sector and } \\
\text { third sector. }\end{array}$ & $\begin{array}{l}\text { Collaboration; } \\
\text { partnership/partner; }\end{array}$ & $\begin{array}{l}\text { Christensen and Lægreid } \\
\text { (2007); Birrell (2008); Evans } \\
\text { (2009); Currie, Grubnic and } \\
\text { Hodges (2011); Shaw (2013) } \\
\text { Kippin, Stoker and Griffiths } \\
\text { (2013); Schiavo-Campo and } \\
\text { McFerson (2014); O'Flynn, } \\
\text { Blackman and Halligan (2013); } \\
\text { Dubnick and Frederickson } \\
\text { (2010); Fossestøl, Breit, } \\
\text { Andreassen and Klemsdal } \\
\text { (2015); Greve, Lægreid and } \\
\text { Rykkja (2016), Menicucci \& } \\
\text { Gontijo (2016). }\end{array}$ \\
\hline
\end{tabular}

\begin{tabular}{|c|c|c|c|}
\hline Network & $\begin{array}{l}\text { Networking in the } \\
\text { provision of public } \\
\text { services (formulation, } \\
\text { implementation, and } \\
\text { control). }\end{array}$ & $\begin{array}{l}\text { Networks; network } \\
\text { management; network } \\
\text { governance. }\end{array}$ & $\begin{array}{l}\text { Christensen and Lægreid } \\
\text { (2007); Evans (2009); } \\
\text { Goldfinch and Wallis (2010); } \\
\text { Lodge and Gill (2011); Currie et } \\
\text { al. (2011); Pérez-López, Prior } \\
\text { and Zafra-Gómez (2015); } \\
\text { Meynhardt and Diefenbach } \\
\text { (2012); O'Flynn et al. (2013); } \\
\text { Fossestøl et al. (2015); Greve et } \\
\text { al. (2016). }\end{array}$ \\
\hline $\begin{array}{l}\text { Integrated and Holistic } \\
\text { Approach of Public } \\
\text { Management }\end{array}$ & $\begin{array}{l}\text { The premise of } \\
\text { integrated public } \\
\text { services and } \\
\text { administrative } \\
\text { perspective of } \\
\text { government as a } \\
\text { whole, cohesive and } \\
\text { coherent (not } \\
\text { fragmented or } \\
\text { competitive) - joined- } \\
\text { up government and } \\
\text { whole of government. }\end{array}$ & $\begin{array}{l}\text { Integration; } \\
\text { integrality; } \\
\text { transversality; cross- } \\
\text { cutting; government } \\
\text { cohesion; government } \\
\text { coherence; whole-of- } \\
\text { government; joined- } \\
\text { up government. }\end{array}$ & $\begin{array}{l}\text { Dunleavy, Margetts, Bastow } \\
\text { and Tinkler (2006); Christensen } \\
\text { and Lægreid (2007); Birrell } \\
\text { (2008); Goldfinch and Wallis } \\
\text { (2010); Pierre and Ingraham } \\
\text { (2010); Lodge and Gill (2011), } \\
\text { Pérez-López et al. (2015); } \\
\text { Kippin et al. (2013); Schiavo- } \\
\text { Campo and McFerson (2014); } \\
\text { O'Flynn et al. (2013); Fossestøl } \\
\text { et al. (2015); Greve et al. } \\
\text { (2016). }\end{array}$ \\
\hline
\end{tabular}


Table 1 (continued)

\begin{tabular}{|c|c|c|c|}
\hline Principles and Guidelines & Meaning & Keywords & Authors \\
\hline Accountability & $\begin{array}{l}\text { Processes of } \\
\text { increasing } \\
\text { accountability and } \\
\text { responsiveness of } \\
\text { public administration } \\
\text { to society. }\end{array}$ & $\begin{array}{l}\text { Accountability; } \\
\text { responsiveness; } \\
\text { transparency. }\end{array}$ & $\begin{array}{l}\text { Dunleavy et al. (2006); } \\
\text { Goldfinch and Wallis (2010); } \\
\text { Pierre and Ingraham (2010); } \\
\text { Shaw (2013) Schiavo-Campo } \\
\text { and McFerson (2014); Dommett } \\
\text { and Flinders (2015); Dubnick } \\
\text { and Frederickson (2010); } \\
\text { Menicucci and Gontijo (2016). }\end{array}$ \\
\hline $\begin{array}{l}\text { Participation and } \\
\text { Engagement }\end{array}$ & $\begin{array}{l}\text { Expand social } \\
\text { participation channels } \\
\text { in policymaking and } \\
\text { foster the involvement } \\
\text { of society in public } \\
\text { management as a } \\
\text { value and source of } \\
\text { legitimacy. }\end{array}$ & $\begin{array}{l}\text { Social control; } \\
\text { participation; } \\
\text { engagement; social } \\
\text { articulation; power } \\
\text { sharing; participatory } \\
\text { democracy; sharing; } \\
\text { involvement; } \\
\text { inclusion (in decision- } \\
\text { making). }\end{array}$ & $\begin{array}{l}\text { Goldfinch and Wallis (2010); } \\
\text { Pierre and Ingraham (2010); } \\
\text { Pérez-López et al. (2015); } \\
\text { Fenwick and McMillan (2012); } \\
\text { Shaw (2013); Dommett and } \\
\text { Flinders (2015); Greve et al. } \\
\text { (2016); Menicucci and Gontijo } \\
\text { (2016). }\end{array}$ \\
\hline Leadership & $\begin{array}{l}\text { Importance of the } \\
\text { leader (political, } \\
\text { administrative or } \\
\text { citizen) in public } \\
\text { management, } \\
\text { especially in } \\
\text { entrepreneurial } \\
\text { processes. }\end{array}$ & $\begin{array}{l}\text { Manager; boss; } \\
\text { direction; leader; } \\
\text { leadership; political } \\
\text { conduction; strategic } \\
\text { direction; } \\
\text { entrepreneurship; } \\
\text { technical direction. }\end{array}$ & $\begin{array}{l}\text { Goldfinch e Wallis ( } 2009 \text {, } \\
\text { 2010); Pierre e Ingraham } \\
\text { (2010); O'reilly e Reed (2010); } \\
\text { Currie et al. (2011); O'Flynn et } \\
\text { al. (2013); Menicucci e Gontijo } \\
\text { (2016). }\end{array}$ \\
\hline Coordination and Control & $\begin{array}{l}\text { Strengthening the } \\
\text { coordination and } \\
\text { control capacities to } \\
\text { generate coherence } \\
\text { and cohesion in } \\
\text { public services. }\end{array}$ & $\begin{array}{l}\text { Coordination; control; } \\
\text { management; } \\
\text { direction; command; } \\
\text { supervision; } \\
\text { articulation; } \\
\text { arrangement; } \\
\text { monitoring. }\end{array}$ & $\begin{array}{l}\text { Christensen and Lægreid } \\
\text { (2007); Goldfinch and Wallis } \\
\text { (2010); Lodge and Gill (2011); } \\
\text { Pérez-López et al. (2015); } \\
\text { Dommett and Flinders (2015); } \\
\text { Greve et al. (2016). }\end{array}$ \\
\hline $\begin{array}{l}\text { E-government and } \\
\text { Information and } \\
\text { Communications Technology } \\
\text { (ICT) }\end{array}$ & $\begin{array}{l}\text { Frequent } \\
\text { incorporation of ICT } \\
\text { to increase } \\
\text { transparency in the } \\
\text { public sector and } \\
\text { enable citizen access } \\
\text { and involvement. }\end{array}$ & $\begin{array}{l}\text { ICT; e-government; } \\
\text { information } \\
\text { technology; digital } \\
\text { government; } \\
\text { electronic } \\
\text { government; e-gov; } \\
\text { information system; } \\
\text { transparency. }\end{array}$ & $\begin{array}{l}\text { Dunleavy et al. (2006); } \\
\text { Goldfinch and Wallis (2009, } \\
\text { 2010); Dubnick and } \\
\text { Frederickson (2010); Greve et } \\
\text { al. (2016). }\end{array}$ \\
\hline $\begin{array}{l}\text { Strengthening Public } \\
\text { Bureaucracy }\end{array}$ & $\begin{array}{l}\text { Professionalization } \\
\text { and appreciation of } \\
\text { the state's staff, with a } \\
\text { more efficient and } \\
\text { interdisciplinary } \\
\text { bureaucracy that is } \\
\text { responsive to society. }\end{array}$ & $\begin{array}{l}\text { Training; } \\
\text { improvement; } \\
\text { professionalism; } \\
\text { specialization; } \\
\text { qualification; } \\
\text { appreciation; } \\
\text { recognition; } \\
\text { empowerment } \\
\text { (bureaucracy). }\end{array}$ & $\begin{array}{l}\text { Dunleavy et al. (2006); } \\
\text { Goldfinch and Wallis (2009); } \\
\text { Lodge and Gill (2011); Pérez- } \\
\text { López et al. (2015); Kippin et } \\
\text { al. (2013). }\end{array}$ \\
\hline
\end{tabular}

Note. Source: Own elaboration.

First, it should be stressed that the reviewed studies address principles and guidelines other than those listed in the table above, such as efficiency and quality of public services, equity, decentralization, 
citizen focus, among others. However, these references are much less frequent. Most of them are closely associated with the first and second generation NPM, which does not suggest that they are unimportant or outdated. They remain on the public administration agenda but they are no longer innovative trends and, consequently, do not lead to the current public management debate.

Secondly, the tables show the recurrence of several principles/guidelines in the literature, which was expected since the complexity of public administration calls for public sector functions that meet different perspectives and needs. The clustering of principles/guidelines is not new since they co-existed even in the traditional (bureaucratic) administration and in the original version of the New Public Management. Thus, they can normally be analyzed jointly. As an example, whole-of-government largely presupposes emphasis on coordination and control of government activities.

Likewise, collaborative and partnerships in public services may involve networking between players from both inside and outside government. Such a finding converges with the statement of Greve et al. (2016, p. 157) that, "Like NPM, post-NPM can to some extent be seen as a 'shopping basket' of different methods." Therefore, innovative changes in public management, in processes and services, are expected to stem from the mix of these tendencies and not necessarily from a restricted focus on one of them.

\section{Innovations in the Federal Government}

\section{The Federal Award of Public Management Innovation (FAPMI)}

Before discussing the extent to which innovations in the Brazilian government converge or diverge with the trends of international public administration, in this subsection, we briefly present how the Federal Award of Public Management Innovation (FAPMI) operates.

The National School of Public Administration (Enap) has annually conducted the FAPMI since 1996. Besides the inspirational goal, the prize has provided a wide source of data for studies and research aimed at increasing knowledge about innovation in public management. The reports of the winning initiatives are available on an online database that, in the last two decades, researchers have used as a secondary source for a variety of studies and publications (Cavalcante, Camoes, Cunha, \& Severo, 2017).

The award defines innovation as a change in a previous practice by incorporating new elements of public administration or a new combination of existing mechanisms that produce significant results in the public service ${ }^{(3)}$. The primary focus of FAPMI is public management activities, projects, and programs at federal level, including the wide range of public organizations.

In general, the award comprises several steps. First, the invitation is mailed to all federal government agencies and released by email and social media. Secondly, candidates submit their applications consisting of a form with descriptive questions and a self-evaluation of results and contributions from June to August. On average, over one hundred applications are submitted nationwide. Then, the assessment processes begin, in which members of the judging committee, composed of senior civil servants, scholars, and consultants specialized in public sector innovation, evaluate every validated initiative based on the following rating criteria:

- Efficient use of resources;

- Degree of sustainability of initiative implementation and results;

Impact of the initiative outputs in terms of problem-solving, meeting the demand of the target audience or the citizens' rights; 
- Innovation over previous practices (new elements and processes);

- Integration with other internal initiatives, external or partnerships;

Civil servant participation and involvement;

Promotion of transparency, participation or social control.

After this stage, the committee selects twenty (20) initiatives for the final round. The committee is visited by members of the technical committee, composed of civil servants with graduate degrees and considerable practical experience in different fields of public administration. During the visit, the innovation leaders must answer several questions previously formulated by the judging committee and demonstrate the initiatives' outputs. At the end of the year, both committees meet to discuss all twenty nominees and, finally, the judging committee selects the ten most innovative initiatives. By March, an official ceremony is held to present the winners and the final classification. In addition to the awards, foreign embassies usually arrange international technical visits to the best-ranked winners. During the last two decades, the prize has changed several times to improve the criteria and selection procedures of the winning initiatives. From 2007 to 2015, the methodology described above maintained the same criteria, categories and processes, which enables the use of these innovations comparatively as a unit of analysis.

Similarly, the FAPMI has undergone a series of changes since 2017. The target audience was extended to include state-level organizations and the award categories and assessment criteria were modified. For instance, the technical visits and ranking decisions of the judging committee were replaced with assessments of the finalist team.

\section{Empirical analysis}

To analyze the way Brazilian innovations are inserted in the current public management debate, we used the principles/directives and their meanings, shown in Table 1, as a protocol. Thus, the aim was to identify the presence of management trends in the 20 annual and 180 total runner-up and winner reports of the Federal Public Management.

The initiatives reports were categorized using content analysis ${ }^{(4)}$ based on the keywords related to the meaning of the trends. This process consisted of three steps: (a) construction of categories (trends); (b) analysis and categorization of each initiative by two research assistants, separately, guided by the protocol description; and (c) validation by the author in case of disagreements. The database is composed of dummy variables (binary dichotomous) with 0 (zero) if the principle/directive is not identified and one (1) when it is identified. Then, we employed descriptive and networking analysis to discuss the results.

Figure 1 depicts the trend distribution identified in the FAPMI initiatives, including all analyzed initiatives - ninety (90) winners and ninety (90) nominees that were not awarded. Some interesting findings can be drawn from this figure. First, the Brazilian federal government, represented by its management innovations, has definitely followed the public administration trends mapped by the international literature. In spite of the diversified adherence to these trends, its convergence is evident. This result is even more striking when we consider that only thirteen (13) innovations did not follow any post-NPM trend. In other words, only 93\% of the FAPMI initiatives show one re more aspects covered by the research protocol.

In quantitative terms, the occurrence of collaboration and partnership seems to maintain the lead identified in the literature review. In this case, almost $2 / 3$ of the Brazilian innovations (117) somehow incorporate components of this trend. The following components are coordination/control and participation/engagement with 61 and 59 cases, respectively. At the bottom of the list, leadership (26) and network (25) are the least reported by the innovations staff. It is a surprising finding because the literature strongly argues that they are crucial drivers of public sector innovation (De Vries et al., 2016) 


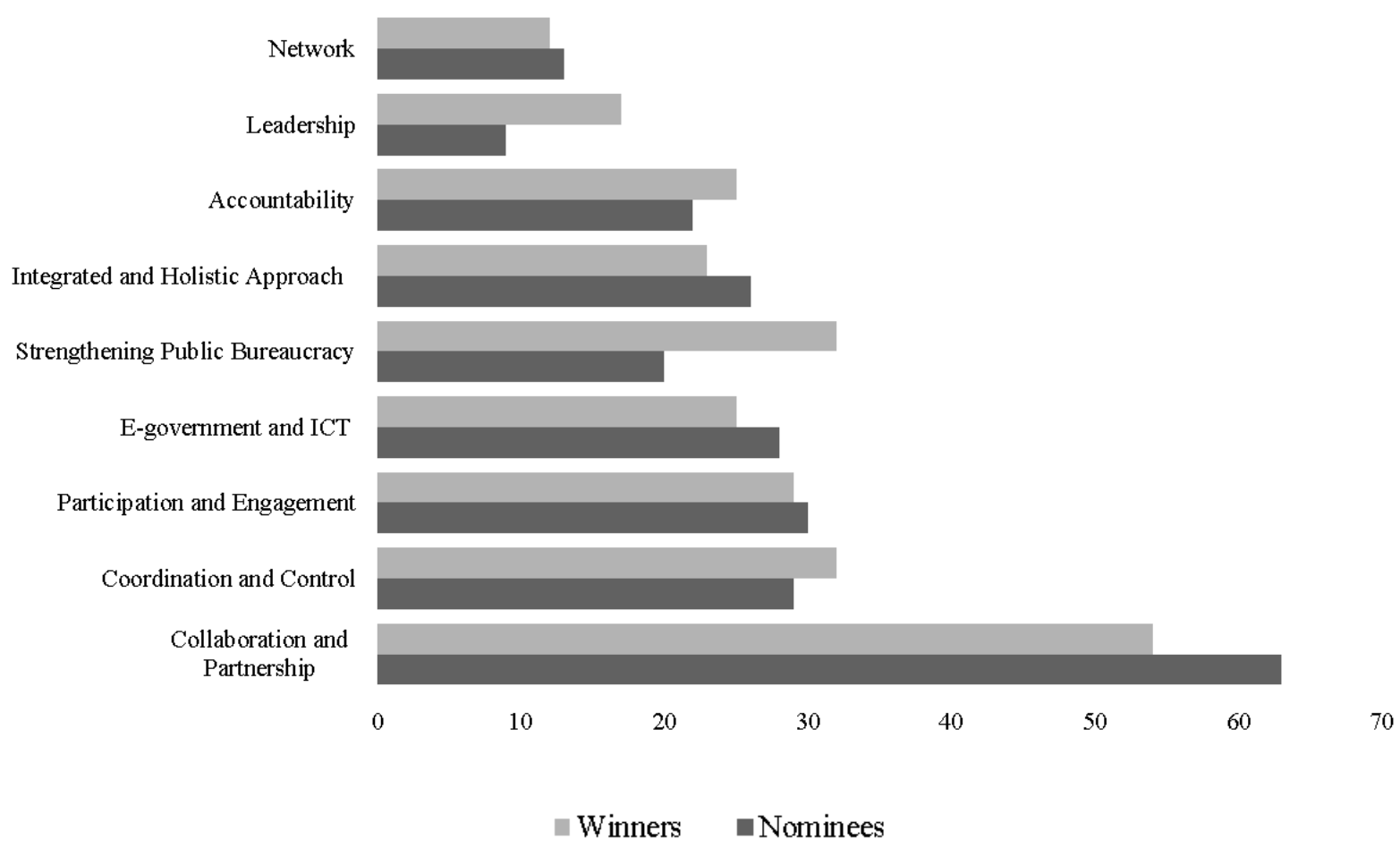

Figure 1. Management Trends' Distribution among Federal Government Innovations Source: Own elaboration.

The presence of principles and guidelines normally follows a similar pattern between FAPMI winners and nominees. As the bar chart shows, in six of the nine trends, the difference is quite small (less than $10 \%$ of initiatives). Nevertheless, in collaboration and partnership, the amount of awarded innovations is significantly less than that of the nominees. The opposite occurs in leadership and strengthening public bureaucracy, suggesting the former trend is so widespread among the initiatives that it was not valued as innovative by the judges in comparison with the latter trend.

Another way of looking at the principles/directives in the public administration according to its innovations is from a longitudinal perspective. In this perspective, the main purpose is to explore possible changes in post-NPM trends occurring in the analyzed period. For this purpose, Figure 2 shows their distribution in all 180 innovations, disaggregated by FAPMI editions. 


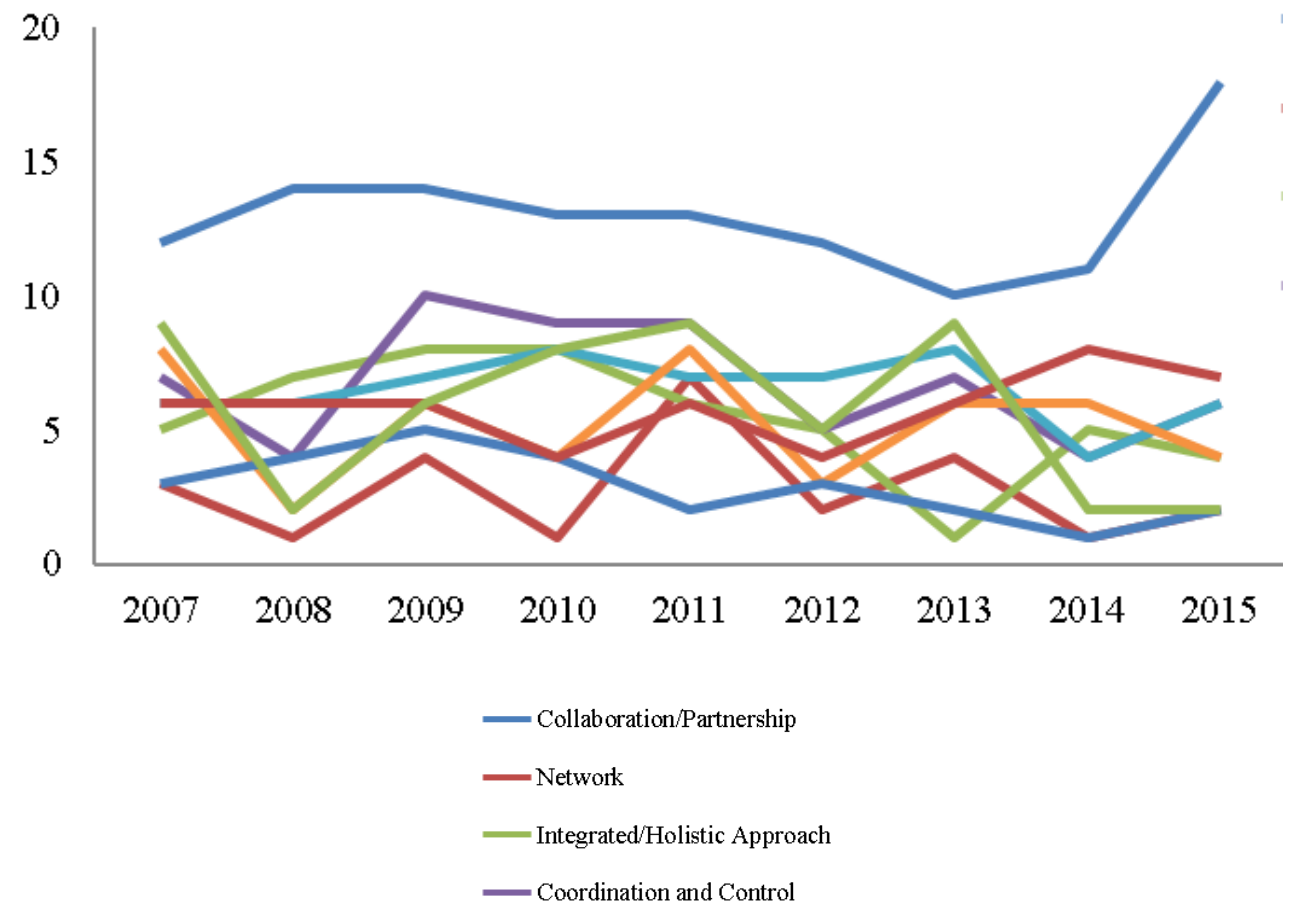

Figure 2. Management Trend Distribution, By Year

Source: Own elaboration.

First, the lack of uniformity emerges in almost every management principle and directive. With the exception of collaboration and partnership with less intensive variations, the remaining trends show significant fluctuations. This result may suggest that the Brazilian federal government innovations have followed the international trends although their occurrence has not altered during the period. In any case, nine years is a relatively short period to demonstrate such a turnover.

On average, a FAPMI initiative has reported 2.7 trends. The small difference between winners (2.6) and nominees (2.76) was unexpected and the opposite seems more plausible. Evidently, it does not mean that every one of them has the same importance in the innovation process. Regardless, we did not analyze this aspect due to the lack of information.

Another result worth mentioning is the clustering of principles/directives. During the policymaking, not one by many trends may influence the implementation process. As expected and in line with the idea of post-NPM as a 'shopping basket' of different methods (Greve et al., 2016), Figure 3 clearly depicts convergences among the management principles/directives. It also shows the relationship of the trend in a network view of their connections. The thicker the lines, the more intense their convergences. 


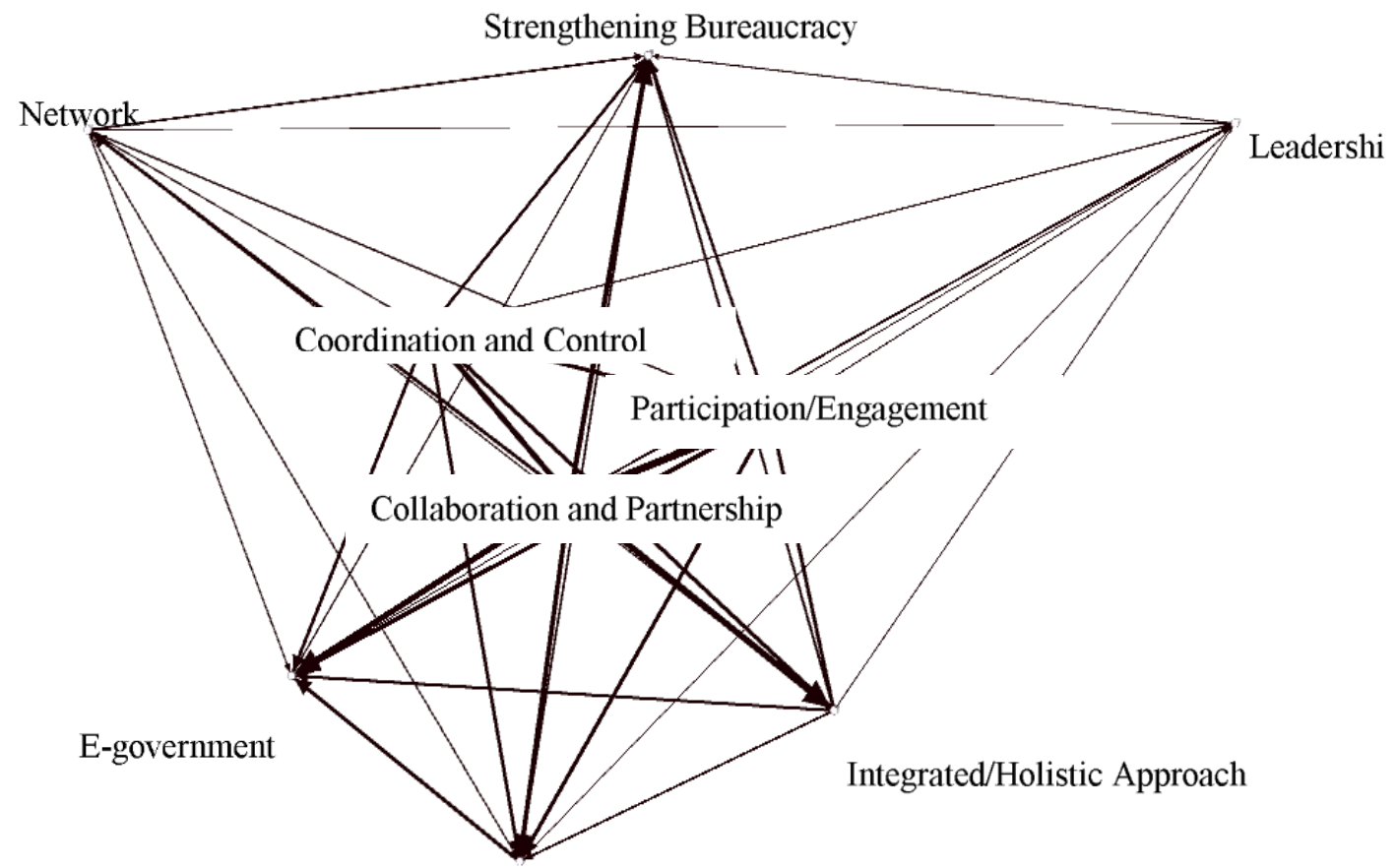

Accountability

Figure 3. Relationship among Management Trends

Source: Own elaboration.

Collaboration and partnership cover almost $2 / 3$ of the innovations; hence, the trend is positioned in the center of the network although it is not necessarily equally related to all the other trends. In this particular case, over $80 \%$ of the initiatives within the network, participation/engagement, and integrated/holistic approach also include some type of partnership in their policymaking. In contrast, the further the principles/directives are from the center, the less likely they are to be reported in the innovations, as in the cases of network and leadership.

As mentioned previously, it would be reasonable to believe that the integrated and holistic approach presupposes emphasis on coordination and control of government activities. To a certain extent, the empirical analysis confirms this expectation since $50 \%$ of the innovations with coordination and control were also mapped to the presence of integrated and holistic approach.

Regarding e-government and information and communications technology, i.e., incorporating ICT to increase transparency and provide citizens' access to and involvement in the public sector, as expected, a convergence was identified with participation/engagement and accountability. In both cases, around $50 \%$ of these trends are also found in innovations with e-government. On the other hand, the latter is barely related to network, leadership, and strengthening bureaucracy.

In addition to these analyses, a question that comes to mind is do the trends vary according to the innovation type? Table 2 helps to answer the question by relating management principles/directives with innovations grouped into different thematic areas. During the FAPMI application process, the manager responsible for the initiative has to define in which area to categorize the innovation.

Although the trends vary according to the predominance of thematic areas, the prevalence of different patterns is evident. To begin with, the most common area, new arrangement for management and policy, with 46 initiatives, tends to be in almost every case based on collaboration and partnership (93\%). Moreover, this type of innovation is in line with participation and engagement (48\%) and holistic approach (46\%). Surprisingly, networking and leadership do not seem to influence the initiatives that focus on implementing new institutional arrangements, at least in the FAPMI cases. 
Table 2

Management Trends, by Innovation Thematic Area

\begin{tabular}{|c|c|c|c|c|c|c|c|}
\hline & $\begin{array}{c}\text { New } \\
\text { Arrangement } \\
(46)\end{array}$ & $\begin{array}{c}\text { Process } \\
\text { ts Improvemen } \\
\text { (37) }\end{array}$ & $\begin{array}{c}\text { Information } \\
\text { t Management } \\
\text { (35) }\end{array}$ & $\begin{array}{c}\text { Citizen } \\
\text { Service } \\
(23)\end{array}$ & $\begin{array}{l}\text { Monitoring } \\
\text { and } \\
\text { Evaluation } \\
\quad(15)\end{array}$ & $\begin{array}{c}\text { Planning } \\
\text { and } \\
\text { Budgeting } \\
(15)\end{array}$ & $\begin{array}{c}\text { Human } \\
\text { Resources } \\
\text { Management } \\
\text { (9) }\end{array}$ \\
\hline $\begin{array}{l}\text { Collaboration and } \\
\text { Partnership }\end{array}$ & $93 \%$ & $46 \%$ & $60 \%$ & $78 \%$ & $73 \%$ & $33 \%$ & $33 \%$ \\
\hline Network & $17 \%$ & $11 \%$ & $14 \%$ & $17 \%$ & $13 \%$ & $7 \%$ & $11 \%$ \\
\hline $\begin{array}{l}\text { Integrated/Holistic } \\
\text { Approach }\end{array}$ & $46 \%$ & $11 \%$ & $29 \%$ & $22 \%$ & $27 \%$ & $33 \%$ & $0 \%$ \\
\hline $\begin{array}{l}\text { Coordination and } \\
\text { Control }\end{array}$ & $24 \%$ & $38 \%$ & $43 \%$ & $13 \%$ & $67 \%$ & $53 \%$ & $0 \%$ \\
\hline $\begin{array}{l}\text { Participation and } \\
\text { Engagement }\end{array}$ & $48 \%$ & $27 \%$ & $46 \%$ & $22 \%$ & $20 \%$ & $7 \%$ & $22 \%$ \\
\hline Accountability & $20 \%$ & $22 \%$ & $37 \%$ & $30 \%$ & $47 \%$ & $7 \%$ & $22 \%$ \\
\hline Leadership & $9 \%$ & $14 \%$ & $17 \%$ & $13 \%$ & $7 \%$ & $20 \%$ & $44 \%$ \\
\hline $\begin{array}{l}\text { E-government and } \\
\text { ICT }\end{array}$ & $28 \%$ & $30 \%$ & $43 \%$ & $30 \%$ & $33 \%$ & $13 \%$ & $0 \%$ \\
\hline $\begin{array}{l}\text { Strengthening } \\
\text { Public } \\
\text { Bureaucracy }\end{array}$ & $20 \%$ & $27 \%$ & $31 \%$ & $35 \%$ & $47 \%$ & $27 \%$ & $33 \%$ \\
\hline
\end{tabular}

Note. Source: Own Elaboration.

In order to improve the public sector's internal processes, collaboration and partnership (46\%) also become relevant, followed by coordination and control (38\%), and e-gov (30\%). However, information management innovations seem to be even more affected by the post-NPM principles/directives. In this case, not only are the trends shown above more frequent, participation and engagement (46\%), accountability (37\%) and holistic approach (29\%) also become influential.

Although service innovation has dominated the practice and field of study in the public sector, in the Brazilian Federal Award, it represents only 23 of the 180 nominated initiatives. Due to the importance of citizen service to the current debate of public administration, the question is which management trends are required for its implementation? This research shows, as the previous types, the occurrence of collaboration and partnership, accountability and e-gov. Moreover, innovations in 1/3 of the cases focus on strengthening bureaucracy and improving the services provided.

Monitoring and evaluation strategies are imperative in public management and this tendency has spread worldwide during the NPM Era. Our findings, however, show that it has not significantly changed since it is usually the thematic area that is most influenced by the trends, especially coordination and control (67\%), accountability (47\%), and strengthening the public service.

The last two types of innovations - planning and budgeting and human resources management (HR) - show different patterns. One reason could be that collaboration and networks are not essential for their internal needs. Although coordination and control (53\%) and integrated approach (33\%) are the recurring trends in initiatives related to financial means, in the HR innovations these post-NPM principles/directives do not appear in any Brazilian Federal innovation. As expected, however, planning and budgeting have strengthening bureaucracy (33\%) and, above all, leadership (44\%) as the most frequent trends. 


\section{Final Remarks}

Considering the relevance of the socioeconomic and service improvements in Brazil in the last two decades and the fact that the economic explanation for these improvements seems incomplete, one alternative research strategy relies on investigating how the public administration has evolved over these years. One way of addressing this subject is to analyze how the government has operated in this period of constant changes. Therefore, the present paper assumes that innovations within the federal government in Brazil have followed the trends of international public management, especially in the post-NPM era. In doing so, it has generated improvements in the access to and quality of public services and, subsequently, influenced better socioeconomic indicators.

The present paper investigates, grounded in exploratory descriptive research, the policy innovations in the Brazilian public sector and their convergence with the trends of international public administration in terms of management principles and directives.

To do so, we initially conducted a comprehensive literature review to map the post- NPM trends. For the review, we systematically analyzed the final round initiatives of the Federal Award of Public Management Innovation (FAPMI) from 2007 to 2015 to find the principles and directives in the reports. The findings of the content analysis are very interesting from a range of perspectives. First, in the Workers' Party administration, known for its appositive view of NPM reforms, most of the management innovations followed international trends. Less than $10 \%$ of the trends do not include any principle/directive covered by the research protocol. Hence, we can confirm the hypothesis that the Brazilian federal government's best practices are in line with the cutting-edge processes and services in public administration. Although the occurrence of principles/directives in the innovations is quite diverse, these trends are undoubtedly convergent.

The paper also showed that the recurrent trends are collaboration/partnership, while coordination/control and participation/engagement had minor differences between the FAPMI runnersup and winners. However, these results must be analyzed with caution because these directives are also correlated to FAPMI's criteria, which bring endogeneity to these findings. In other words, the presence of these trends in innovations can be by the fact that the assessment dimensions are highly related to the trends. As expected, the initiatives have more than one trend - on average 2.7 trends were reported. However, the network analysis provided an overview of the management principles/directives clustering, which clearly confirms the managers rely on combinations of trends in order to implement successful policies that do not necessarily follow pre-defined guidelines.

Finally, the inquiry compared whether the trends vary according to the innovation type, depicted by their thematic areas. Once again, heterogeneity among them was the rule. The recurrent type was new arrangement, which is connected with collaboration and partnership. Internal ends initiatives, such as planning and budgeting and HR management, cover fewer trends but they also seem to hold some post-NPM principles/directives that are less usual than strengthening bureaucracy and leadership.

Regarding the research limitations, the empirical results must evidently be analyzed with some caution from the trend identification stem from the managers' reports. In addition, the winning initiatives are the ones known as champions or best practices. Therefore, they do not necessarily reflect the ordinary process and service in Brazilian public management. However, this is an analytical strategy increasingly used to explore public sector innovations (Borins, 2014), including in the field of study in Brazil (Cavalcante et al., 2017).

This article presents original findings of the public administration framework grounded in the current theoretical debate and empirical data. Thus, it contributes not only to scholars but also provides information for policymakers to reflect on how to formulate and implement their policies. This kind of research is critical because the debate about public management is often contaminated by simplistic and stereotypical views. Consequently, these shortcomings tend to generate problems of excessive prescriptivism in the reform proposals and inadequate adaptations to quite different realities. As a 
research agenda, the paper paves the way for qualitative and more detailed approaches regarding how the management trends are implemented and their level of salience on public sector innovations.

\section{Acknowledgements}

I would like to thank the reviewers for the comments and, especially, Amanda Gomes Magalhães and Isabella de Araújo Goellner for their support throughout the paper's research.

\section{Notes}

\footnotetext{
${ }^{1}$ Decree-Law is a type of norm with law effects used by the military regime (1964-1985), however, without need of Legislative process.

2 The list of journals included Journal of Public Administration Research and Theory; Public Administration Review; Governance; International Public Management Journal and; Public Administration.

${ }^{3}$ For more information about FAPMI's rules and procedures, see https://inovacao.enap.gov.br/o-concurso/.

${ }^{4}$ The research used qualitative software (Atlas TI) to help the analysis.
}

\section{References}

Abrucio, F. L. (2007). Trajetória recente da gestão pública brasileira: um balanço crítico e a renovação da agenda de reformas [Edição Especial]. Revista de Administração Pública, 41, 67-86. http://doi.org/10.1590/S0034-76122007000700005

Abrucio, F. L., \& Gaetani, F. (2008). Avanços e perspectivas da gestão pública nos estados: Agenda, aprendizado e coalizão. In L. Costa (Org.), Avanços e perspectivas da gestão pública nos estados (pp. 1-270). Rio de Janeiro: Editora Qualitymark.

Bekkers, V., Edelenbos, J., \& Steijn, B. (Eds.). (2011). Innovation in the public sector. New York: Palgrave Macmillan.

Birrell, D. (2008). The final outcomes of the review of public administration in Northern Ireland. Tensions and compatibility with devolution, parity and modernization. Public Administration, 86(3), 779-793. http://doi.org/10.1111/j.1467-9299.2008.00725.x

Borins, S. F. (2014). The persistence of innovation in government (Vol. 8). Boston: Brookings Institution Press with Ash Center for Democratic Governance and Innovation.

Brulon, V., Ohayon, P., \& Rosenberg, G. (2012). A reforma gerencial brasileira em questão: Contribuições para um projeto em construção. Revista do Serviço Público, 63(3), 265-284.

Cavalcante, P., Camoes, M., Cunha, B., \& Severo, W. (Orgs.). (2017). Inovação no setor público: Teoria, tendências e casos no Brasil. Brasília: Ipea.

Cavalcante, P., \& Carvalho, P. (2017). Profissionalização da burocracia federal brasileira (1995-2014): Avanços e dilemas. Revista de Administração Pública, 51(1), 1-26. http://doi.org/10.1590/00347612144002 
Christensen, T., \& Lægreid, P. (2007). The whole-of-government approach to public sector reform. Public Administration Review, 67(6), 1059-1066. http://doi.org/10.1111/j.15406210.2007.00797.x

Currie, G., Grubnic, S., \& Hodges, R. (2011). Leadership in public services networks: Antecedents, process and outcome. Public Administration, 89(2), 242-264. http://doi.org/10.1111/j.14679299.2011.01931.x

Costa, F. L. da (2008). Brasil: 200 anos de Estado; 200 anos de administração pública; 200 anos de reformas. Revista de Administração Pública, 42(5). http://doi.org/10.1590/S003476122008000500003

De Vries, H., Bekkers, V., \& Tummers, L. (2016). Innovation in the public sector: A systematic review and future research agenda. Public administration, 94(1), 146-166.

Dommett, K., \& Flinders, M. (2015). The politics of quangocide. Policy \& Politics, 43(1), 3-25. https://doi.org/10.1332/030557314X13946412301792

Dubnick, M. J., \& Frederickson, H. G. (Eds.). (2010). Accountable governance: Problems and promises. New York: Routledge.

Dunleavy, P., Margetts, H., Bastow, S., \& Tinkler, J. (2006). New public management is dead-long live digital-era governance. Journal of Public Administration Research and Theory, 16(3), 467494. https://doi.org/10.1093/jopart/mui057

Evans, M. (2009). Gordon brown and public management reform-a project in search of a 'big idea'?. Policy studies, 30(1), 33-51. http://doi.org/10.1080/01442870802576181

Fenwick, J., \& McMillan, J. (2012). Public participation and public service modernization: Learning from new labor?. International Journal of Public Administration, 35(6), 367-378. http://doi.org/10.1080/01900692.2012.655523

Fossestøl, K., Breit, E., Andreassen, T. A., \& Klemsdal, L. (2015). Managing institutional complexity in public sector reform: Hybridization in front-line service organizations. Public Administration, 93(2), 290-306. http://doi.org/10.1111/padm.12144

Gaetani, F. (2003). O recorrente apelo das reformas gerenciais: Uma breve comparação. Revista do Serviço Público, 54(4), 23-43. https://doi.org/10.21874/rsp.v54i4.274

Goldfinch, S., \& Wallis, J. (Eds.). (2009). International handbook of public management reform. Northampton: Edward Elgar Publishing.

Goldfinch, S., \& Wallis, J. (2010). Two myths of convergence in public management reform. Public Administration, 88(4), 1099-1115. http://doi.org/10.1111/j.1467-9299.2010.01848.x

Greve, C., Lægreid, P., \& Rykkja, L. H. (2016). The nordic model revisited: active reformers and high performing public administrations. In C. Greve, P. Lægreid, \& L. H. Rykkja (Eds.), Nordic administrative reforms (pp. 189-212). London: Palgrave Macmillan.

Kippin, H., Stoker, G., \& Griffiths, S. (Eds.). (2013). Public services: A new reform agenda. London: Bloomsbury Academic.

Lodge, M., \& Gill, D. (2011). Toward a new era of administrative reform? The myth of post-npm in New Zealand. Governance, 24(1), 141-166. http://dx.doi.org/10.1111/j.1468-0491.2010.01508.x

Matias-Pereira, J. (2008). Administração pública comparada: Uma avaliação das reformas administrativas do Brasil, EUA e União Européia. Revista de Administração Pública, 42(1), 6182. http://doi.org/10.1590/S0034-76122008000100004 
Menicucci, T., \& Gontijo, J. (2016). Gestão e políticas públicas no cenário contemporâneo: Tendências nacionais e internacionais. Rio de Janeiro: Fiocruz.

Meynhardt, T., \& Diefenbach, F. E. (2012). What drives entrepreneurial orientation in the public sector? Evidence from Germany's federal labor agency. Journal of Public Administration Research and Theory, 22(4), 761-792. https://doi.org/10.1093/jopart/mus013

O'Flynn, J., Blackman, D., \& Halligan, J. (Eds.). (2013). Crossing boundaries in public management and policy: The international experience (Vol. 15). London: Routledge.

O'Reilly, D., \& Reed, M. (2010). 'Leaderism': An evolution of managerialism in UK public service reform. Public Administration, 88(4), 960-978. https://doi.org/10.1111/j.14679299.2010.01864.x

Osborne S., \& Brown, K. (2005) Managing change and innovation in public service organizations. London: Routledge.

Organisation for Economic Co-operation and Development. (2018). Embracing innovation in government global trends 2018. Paris: OECD Publishing.

Pereira, L. C. B. (1999). Reflexões sobre a reforma gerencial brasileira de 1995. Revista do Serviço Público, 50(4), 5-29. Recuperado de http://www.bresserpereira.org.br/papers/1999/662Reflex\%C3\%B5es_Reforma_Gerencial.RSP.pdf. https://doi.org/10.21874/rsp.v50i4.354

Pereira, L. C. B. (2002). Reforma da nova gestão pública: Agora na agenda da América Latina, no entanto. Revista do Serviço Público, 53(1), 5-27. https://doi.org/10.21874/rsp.v53i1.278

Pérez-López, G., Prior, D., \& Zafra-Gómez, J. (2015). Rethinking new public management delivery forms and efficiency: Long-term effects in spanish local government. Journal of Public Administration Research and Theory, 25(4), 1157-1183. https://doi.org/10.1093/jopart/muu088

Pierre, J., \& Ingraham, P. W. (2010). Comparative administration change: Lessons learned. Montreal: McGill-Queen's Press-MQUP.

Pollitt, C., \& Bouckaert, G. (2004). Public management reform: A comparative analysis. Princeton: Oxford University Press.

Schiavo-Campo, S., \& McFerson, H. M. (2014). Public management in global perspective. London: Routledge.

Shaw, R. (2013). Another size fits all? Public value management and challenges for institutional design. Public Management Review, 15(4), 477-500. http://doi.org/10.1080/14719037.2012.664017

Torres, M. (2012). Para entender a política brasileira. Rio de Janeiro: Editora FGV.

\section{Author}

Pedro Cavalcante

SBS Qd. 1, Bloco J, Sala 1211, 70076-900, Brasília, DF, Brasil.

E-mail: cavalcante.pedro@gmail.com 